GLASILO

FUTURE

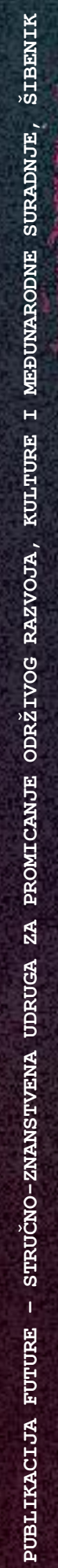

VOLUMEN 1 BROJ 5-6

PROSINAC 2018.

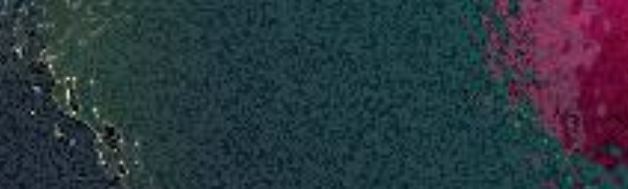

UDK 60

UDK 631

UDK 630

UDK 336

UDK 338
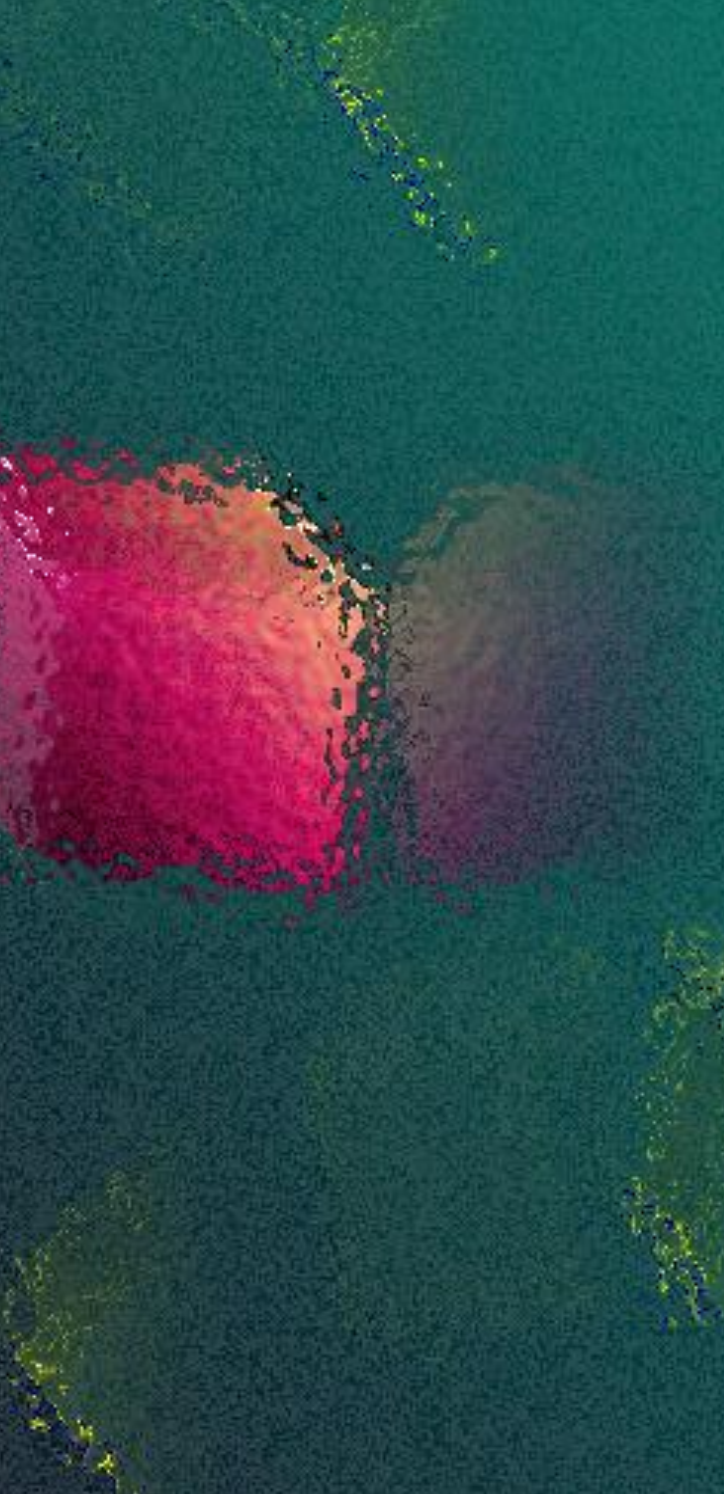


\section{Glasilo Future}

\section{Stručno-znanstveni časopis}

Nakladnik: FUTURA

\section{FUTUR}

Sjedište udruge: Šibenik

\section{Adresa uredništva:}

Bana Josipa Jelačića 13 a, 22000 Šibenik, Hrvatska / Croatia 留 / 圆: +385 (0) 022218133

$\triangle$ : urednistvo@gazette-future.eu / editors@gazette-future.eu (3): www.gazette-future.eu

\section{Uređivački odbor / Editorial Board:}

Doc. dr. sc. Boris Dorbić, v. pred. - glavni i odgovorni urednik / Editor-in-Chief

Emilija Friganović, dipl. ing. preh. teh., v. pred. - zamjenica g. i o. urednika / Deputy Editor-in-Chief

Ančica Sečan Matijaščić, mag. act. soc. - tehnička urednica / Technical Editor

Antonia Dorbić, mag. art. - zamjenica tehničke urednice / Deputy Technical Editor

Prof. dr. sc. Željko Španjol

Mr. sc. Milivoj Blažević

Vesna Štibrić, dipl. ing. preh. teh.

\section{Međunarodno uredništvo / International Editorial Board:}

Prof. dr. sc. Kiril Bahcevandziev - Portugal (Instituto Politécnico de Coimbra)

Prof. dr. sc. Martin Bobinac - Srbija (Šumarski fakultet Beograd)

Doc. dr. sc. Zvezda Bogevska - Makedonija (Fakultet za zemjodelski nauki i hrana Skopje)

Dario Bognolo, mag. ing. - Hrvatska (Veleučilište u Rijeci)

Prof. dr. sc. Agata Cieszewska - Poljska (Szkoła Główna Gospodarstwa Wiejskiego w Warszawie)

Dr. sc. Bogdan Cvjetković, prof. emeritus - Hrvatska (Agronomski fakultet Zagreb)

Prof. dr. sc. Duška Ćurić - Hrvatska (Prehrambeno-biotehnološki fakultet Zagreb)

Doc. dr. sc. Margarita Davitkovska - Makedonija (Fakultet za zemjodelski nauki i hrana Skopje)

Doc. dr. sc. Dubravka Dujmović Purgar - Hrvatska (Agronomski fakultet Zagreb)

Prof. dr. sc. Semina Hadžiabulić - Bosna i Hercegovina (Agromediteranski fakultet Mostar)

Prof. dr. sc. Péter Honfi - Mađarska (Faculty of Horticultural Science Budapest)

Prof. dr. sc. Valeria Ivanova - Bugarska (Fakultet za lozaro-gradinarstvo Plovdiv)

Doc. dr. sc. Orhan Jašić - Bosna i Hercegovina (Filozofski fakultet Tuzla)

Prof. dr. sc. Tajana Krička - Hrvatska (Agronomski fakultet Zagreb)

Prof. dr. sc. Biljana Lazović - Crna Gora (Biotehnički fakultet Podgorica)

Prof. dr. sc. Bosiljka Mustać - Hrvatska (Sveučilište u Zadru)

Hrv. akademik prof. dr. sc. Stanislav Nakić - Bosna i Hercegovina (Sveučilište Hercegovina Mostar)

Sandra Popović, mag. ing. - Srbija (Poljoprivredni fakultet Beograd)

Doc. dr. sc. Bojan Simovski - Makedonija (Šumarski fakultet Skopje)

Prof. dr. sc. Davor Skejić - Hrvatska (Građevinski fakultet Zagreb)

Doc. dr. sc. Milan Stanković - Srbija (Univerzitet u Kragujevcu)

Akademik prof. dr. sc. Refik Šećibović - Bosna i Hercegovina (Visoka škola za turizam i menadžment Konjic)

Prof. dr. sc. Andrej Šušek - Slovenija (Fakulteta za kmetijstvo in biosistemske vede Maribor)

Prof. dr. sc. Elma Temim - Bosna i Hercegovina (Agromediteranski fakultet Mostar)

Doc. dr. sc. Ivana Vitasović Kosić - Hrvatska (Agronomski fakultet Zagreb)

Doc. dr. sc. Ana Vujošević - Srbija (Poljoprivredni fakultet Beograd)

Prof. dr. sc. Vesna Židovec - Hrvatska (Agronomski fakultet Zagreb)

Lektura i grafička priprema: Ančica Sečan Matijaščić, mag. act. soc.

Objavljeno: 31. prosinca 2018. godine.

Časopis izlazi u elektroničkom izdanju dva puta godišnje, krajem lipnja i prosinca, a predviđena su i dva interdisciplinarna specijalna izdanja tijekom godine iz STEM i ostalih znanstvenih/umjetničkih područja.

Časopis je besplatan. Rukopisi i recenzije se ne vraćaju i ne honoriraju.

Umnožavanje (reproduciranje), stavljanje u promet (distribuiranje), priopćavanje javnosti, stavljanje na raspolaganje javnosti odnosno prerada u bilo kojem obliku nije dopuštena bez pismenog dopuštenja Nakladnika. Sadržaj objavljen u Glasilu Future može se slobodno koristiti u osobne i obrazovne svrhe uz obvezno navođenje izvora. 


\section{Glasilo Future}

\section{Stručno-znanstveni časopis}

FUTURA - stručno-znanstvena udruga za promicanje održivog razvoja, kulture i međunarodne suradnje, Bana Josipa Jelačića 13 a, 22000 Šibenik, Hrvatska

(2018) $1(5-6) 01-52$

\section{SADRŽAJ:}

\section{Izvorni znanstveni rad (original scientific paper)}

Str.

B. Dorbić, Lea Zemunović, Tea Zemunović, Emilija Friganović, Elma Temim, Katica Arar

Istraživanje općih saznanja o nekim vrstama trajnica na Mediteranu

A research on common knowledge about some perennial species in the Mediterranean region

Branka Stipanović

Stavovi maslinara o podizanju konkurentnosti maslinarstva u Dalmaciji u kontekstu ARISTOIL projekta

Attitudes of olive growers in Dalmatia region about competiveness growth in context of ARISTOIL project

\section{Stručni rad (professional paper)}

\section{Blažević}

Ogled o urbanim i prirodnim vrijednosnicama Šibenika u kontekstu turističke perspektive

An overview of urban and natural values of Šibenik in the context and from tourism perspective

J. E. Meeker, Z. Lišnić, B. Dorbić, Emilija Friganović, Ž. Španjol, Zvezda Bogevska Mogućnosti uporabe nekih jestivih submediteranskih autohtonih i alohtonih vrsta za održive dekorativne vrtove na kršu

Opportunities for use of some edible sub-Mediterranean autochthonous and allochthonous species for sustainable ornamental gardens in karst landscapes

\section{Nekategorizirani rad (uncategorised paper)}

\section{Zdenka Bilušić}

Vijesti

News 
B. Dorbić, Lea Zemunović, Tea Zemunović, Emilija Friganović, Elma Temim, Katica Arar / Istraživanje općih saznanja o nekim vrstama trajnica na Med... / Glasilo Future (2018) 1 (5-6) 01-12

\title{
Istraživanje općih saznanja o nekim vrstama trajnica na Mediteranu
}

\section{A research on common knowledge about some perennial species in the Mediterranean region}

\author{
Boris Dorbić $^{1 *}$, Lea Zemunović ${ }^{1,2}$, Tea Zemunović ${ }^{1,2}$, Emilija Friganović ${ }^{1}$, \\ Elma Temim ${ }^{3}$, Katica Arar ${ }^{4}$
}

izvorni znanstveni rad (original scientific paper)

doi: $10.32779 /$ gf.1.5-6.1

\section{Sažetak}

Trajnice ili perene su biljne vrste koje žive dvije ili više godina. Najraznolikija su skupina ukrasnog bilja koja pokazuje veliku raznolikost oblika, boja, formi, teksture i mirisa. Tijekom svoje duge sezone rasta zahtijevaju malo njege. Neke od njih uspijevaju u močvarnim uvjetima, a većina ih zahtijeva prikladno melioriranu vrtnu zemlju koja sadrži dosta humusa. Većina ovih biljaka može se razmnožavati vegetativno i generativno. Trajnice se u krajobrazu primjenjuju na sljedeće načine: kao pojedinačne biljke (soliteri), u skupinama, kao pokrivači tla, na kamenjarama, za živice itd. Na Mediteranu se najčešće uzgajaju sljedeće vrste perena: Hedera helix, Cyclamen hederifolium, Sempervivum tectorum, Hydrangea sp., Primula vulgaris, Salvia officinalis, Dianthus barbatus, Chrysanthemum indicum, Lavandula angustifolia, Helichrysum italicum čije su karakteristike dane u ovom radu. Kao izvor primarnih podataka u ovom radu korišteno je anketno istraživanje na području grada Knina i njegove okolice. Cilj anketnog ispitivanja bio je utvrđivanje općih saznanja o pojedinim dekorativnim trajnicama (primjena u krajobrazu, ukrasne karakteristike vrste, način održavanja i utjecaj pojedinačnih vrsta na čovjekovo raspoloženje). Anketno ispitivanje je provedeno tijekom travnja 2017. godine na uzorku od 50 ispitanika. Rezultati istraživanja su pokazali sljedeće: ispitanici primjenu trajnica u krajobrazu i njihove ukrasne karakteristike ocjenjuju vrlo dobrim ocjenama. Način održavanja procjenjuju kao uglavnom lagan, a utjecaju trajnica na čovjekovo raspoloženje su dodijeljene visoke vrlo dobre ocjene.

Ključne riječi: trajnice, ukrasne karakteristike, primjena, percepcije, Mediteran.

\footnotetext{
${ }^{1}$ Veleučilište "Marko Marulić" u Kninu, Krešimirova 30, 22300 Knin, Republika Hrvatska.

* Doc. dr. sc. Boris Dorbić, v. pred., e-mail: bdorbic@veleknin.hr.

${ }^{2}$ Studentice preddiplomskog stručnog studija Poljoprivreda krša, smjer: Biljna proizvodnja.

${ }^{3}$ Agromediteranski fakultet Univerziteta "Džemal Bijedić" u Mostaru, Univerzitetski kampus bb, 88104 Mostar, Bosna i Hercegovina.

${ }^{4}$ Agronomski fakultet Sveučilišta u Mostaru, Nadbiskupa Čule, 88104 Mostar, Bosna i Hercegovina.
} 


\begin{abstract}
Perennials are plant species that live for two or more years. They are the most diverse group of ornamental plants that shows a wide range of forms, colors, forms, textures and scents. They need hardly any care throughout their long growing season. Some of them can be grown in wetland conditions, while most of them require adequately ameliorated humus rich garden soil. Most these plants can be used both for vegetative and generative reproduction. Perennials are used in landscaping in the following ways: as individual plants (solitaires), in groups, as ground cover, in rock gardens and for creating hedges, to name a few. The following perennials are most frequently grown in the Mediterranean: Hedera helix, Cyclamen hederifolium, Sempervivum tectorum, Hydrangea sp., Primula vulgaris, Salvia officinalis, Dianthus barbatus, Chrysanthemum indicum, Lavandula angustifolia and Helichrysum italicum, whose characteristics have been presented in this paper. The findings of the survey research conducted in the Knin area and its outskirts provided the primary sources of information in this paper. The objective of the survey research was to determine the common knowledge about specific ornamental perennials (their use in landscaping, ornamental characteristics of the species, maintenance regimes and impact of individual species on human mood). The survey research was conducted in April 2017 on a sample of 50 respondents. The research findings showed as follows: the respondents evaluated the use of perennials in landscaping and their ornamental characteristics with very good grades. Maintenance regimes were assessed most frequently as easy maintenance, whereas the impact of perennials on human mood was evaluated with high very good grades.
\end{abstract}

Key words: perennials, ornamental characteristics, use, perceptions, Mediterranean.

\title{
Uvod
}

Trajnice su biljke koje žive dvije ili više godina i kao potpuno razvijene biljke cvatu svake godine. Trajnice su najraznolikija skupina ukrasnog bilja koja pokazuje veliku raznolikost: oblika, boja, formi, teksture i mirisa koji uvjetuju njihov odabir pri sadnji i oblikovanju krajobraznih površina. Njihov dobar odabir vrlo brzo stvara na krajobraznoj površini finu teksturu, sklad boja, listova i cvjetova koji će privlačiti poglede mjesecima. Kod nas se na Mediteranu i submediteranu najčešće uzgajaju bršljan (Hedera helix L.), ciklama (Cyclamen hederifolium Aiton.), čuvarkuća (Sempervivum tectorum L.), hortenzija (Hydrangea sp.), jaglac (Primula vulgaris Huds), kadulja (Salvia officinalis L.), turski karanfil (Dianthus barbatus L.), krizantema (Chrysanthemum indicum L.), lavanda (Lavandula angustifolia Mill.), smilje [Helichrysum italicum (Roth) G. Don. fil.] koji će biti opisani u daljnjem dijelu teksta. 

Istraživanje općih saznanja o nekim vrstama trajnica na Med... / Glasilo Future (2018) 1 (5-6) 01-12

Ponuda trajnica uistinu je velika, čak impozantna, jer postoji više tisuća vrsta i još više uzgojenih oblika - sorata. Zbog tako velikog broja trajnice možemo koristiti na svim staništima (Kantoci, 2011, str. 7).

Tijekom svoje duge sezone rasta, trajnice zahtijevaju malo njege. Potrebno ih je redovito zalijevati, osobito u ranom razdoblju dok se biljka ne ukorijeni, uređivati, otkidati uvele cvjetove, prihranjivati. Neke trajnice uspijevaju u močvarnim uvjetima, a većina ih zahtijeva dobro odvodnjenu vrtnu zemlju koja sadrži dosta humusa. Većina ovih biljaka mogu se razmnožavati dijeljenjem busa, vršnim reznicama u rano proljeće, reznicama korijena i sjemenom (Mcdonald, 2003).

Trajnice se na krajobraznim površinama uglavnom formiraju u grupe (1 - 10) ovisno o vrsti. Neke trajnice višeg rasta (divizma) mogu se saditi pojedinačno. Perene se također mogu koristiti za dekorativne kamenjare, alpinetume, rubove travnjaka itd. U novije vrijeme, zbog nedostatka ljudskog vremena za vrt i smanjenja vrtnih prostora, postale su nezamjenjiv ukrasni element (Kantoci, 2011; Dorbić et al., 2018).

Cvjetne vrste seoskih vrtova osim dekorativnosti, uzgajane su $i$ zbog svojeg utilitarnog karaktera. Tako su se brojne biljne vrste uzgajale radi svojih začinskih ili ljekovitih svojstava ili su bile privlačne insektima (Židovec et al., 2006, prema Krajičak et al., 2013).

Cilj rada je istražiti percepciju općih saznanja o pojedinim trajnicama na području Knina, ostalih naselja i susjednih gradova.

\section{Materijali i metode}

Prilikom izrade rada kao izvor sekundarnih podataka korištene su različite publikacije. Kao izvor primarnih podataka korišteno je anketno istraživanje na području grada Knina i njegove okolice. Cilj anketnog ispitivanja bilo je utvrđivanje općih saznanja o pojedinim ukrasnim trajnicama. Anketno ispitivanje je provedeno tijekom travnja 2017. godine na uzorku od 50 ispitanika od kojih je $50 \%$ ispitanika bilo iz Knina, a $50 \%$ iz ostalih naselja i susjednih gradova. Starosna struktura uzorka je sljedeća: do 20 godina (12\% ispitanika), 20 - 30 godina (46\% ispitanika), 30 - 40 godina (14\% ispitanika), 40 - 50 godina (18\% ispitanika) i 50 - 65 godina (10\% ispitanika). U pogledu stupnja obrazovanja struktura uzorka bila je sljedeća: srednja stručna sprema (76\%), viša stručna sprema (8\%), visoka stručna sprema (12\%), znanstveni magisterij i doktorat (4\%). U svrhu statističke izrade korištena je petostupanjska ljestvica (za mjerenje stavova o dekorativnosti i načinu održavanja vrste) s vrijednostima od 1 do 5 . Obrada podataka provedena je mjerilima centralne tendencije odnosno na osnovu izračuna aritmetičke sredine i standardne devijacije. 


\section{Rezultati i rasprava}

Prije rezultata dobivenih anketnim istraživanjem dajemo pregled morfoloških i uzgojnih karakteristika za istraživane trajnice (Tablica 1.).

Tablica 1. Morfološke i uzgojne karakteristike za odabrane vrste trajnica.

Table 1. Morphological and breeding characteristics for selected species of perennials.

\begin{tabular}{|c|c|c|}
\hline & Odabrane trajnice & Morfološke i uzgojne karakteristike \\
\hline & Hedera helix L. - bršljan & $\begin{array}{l}\text { Bršljan je zimzelena trajnica koja naraste } 20-30 \mathrm{~m} \text { u visinu. } \\
\text { Listovi su trostruko do peterostruko krpasti, kožasti ili srcoliki. } \\
\text { Cvjetovi su žutozeleni skupljeni u štitastu cvat. Plodovi su } \\
\text { dekorativne bobice tamnoplave boje (Kreuter, 2008). Vrijeme } \\
\text { cvatnje je u jesen (Šilić, 1990). Otporan je na zimu i uspijeva na } \\
\text { jakom suncu kao i u sjeni. Najbolje raste u propusnom, vlažnom } \\
\text { tlu bogatom humusom (Krauter, 2008). }\end{array}$ \\
\hline & $\begin{array}{l}\text { Cyclamen hederifolium } \\
\text { Aiton - ciklama }\end{array}$ & $\begin{array}{l}\text { Ciklama naraste u visinu od } 1-25 \mathrm{~cm} \text {. Listovi su joj srcoliki, } \\
\text { obrubljeni srebrnkastom čipkom. Cvjetovi se nalaze na dugim } \\
\text { stapkama raznih boja. Vrijeme cvatnje je od zime do proljeća. } \\
\text { Voli djelomično sunčana i sjenovita područja. Preferira humusna i } \\
\text { propusna tla, te djelomično vlažno tlo (Strukić, 2014). }\end{array}$ \\
\hline & $\begin{array}{l}\text { Sempervivum tectorum } \text { L. - } \\
\text { čuvarkuća }\end{array}$ & $\begin{array}{l}\text { Čuvarkuća naraste u visinu od } 15-30 \mathrm{~cm} \text {. Listovi su joj mesnati, } \\
\text { duljine do } 7,5 \mathrm{~cm} \text { i nalaze se u gustim rozetama. Mogu biti } \\
\text { različitim nijansama od zelene, crvene, plavosive i sivozelene } \\
\text { boje. Cvjetovi su zvjezdoliki, promjera } 1,25-2,5 \mathrm{~cm} \text {. Mogu biti } \\
\text { ružičaste, crvene, grimizne, zelenkasto žute ili žućkasto bijele } \\
\text { boje. Cvjeta po ljeti. Preferira sunčane položaje. Nema velike } \\
\text { zahtjeve prema tlu i gnojidbi, uspijeva na suhim i siromašnim } \\
\text { tlima (McDonald, 2003). }\end{array}$ \\
\hline & bort & $\begin{array}{l}\text { Hortenzija može biti listopadni grm ili zimzelena penjačica. } \\
\text { Listovi su nasuprotni, jednostavni, jajoliki, svijetlo zelene boje. } \\
\text { Krupni cvatovi mogu biti široki i pločasti, kupolasti ili potpuno } \\
\text { okrugli u nijansama crvene, plave, ružičaste ili bijele boje. Cvate } \\
\text { od lipnja do rujna. Zahtjeva osunčane i polu sjenovite položaje. } \\
\text { Tlo i gnojidba - najbolje uspijeva na težim i vlažnijim tlima koja } \\
\text { se prihranjuju kompleksnim hranjivom svake godine u proljeće } \\
\text { (Strukić, 2014). }\end{array}$ \\
\hline & $\begin{array}{l}\text { Primula vulgaris Huds - } \\
\text { jaglac }\end{array}$ & $\begin{array}{l}\text { Listovi jaglaca su ovalni, duguljasti i naborani. Cvjetovi su } \\
\text { pojedinačni i izbijaju iz sredine lisne rozete. Mogu biti } \\
\text { jednostavni i puni. Osnovna boja cvijeta je žuta, ali danas postoje } \\
\text { kultivari uzgojeni u gotovo svim bojama. Cvjetaju od kraja } \\
\text { veljače do svibnja. Raste na polusjenovitim položajima. } \\
\text { Odgovaraju mu rahla tla bogata hranivima, te neutralna do } \\
\text { umjereno kisela tla (Strukić, 2014). }\end{array}$ \\
\hline & $\begin{array}{l}\text { Salvia officinalis } \text { L. } \quad- \\
\text { kadulja }\end{array}$ & $\begin{array}{l}\text { Kadulja raste uspravno ili grmoliko. Listovi su srebrno sive do } \\
\text { crvene boje s malim cvjetovima ljubičaste i plavkaste boje. Cvate } \\
\text { od svibnja do srpnja. Voli puno sunca, ali dobro uspijeva i u } \\
\text { polusjeni. Može se uzgajati na svim tipovima tala, ali je vrlo } \\
\text { važna dobra drenaža (Strukić, 2014). }\end{array}$ \\
\hline & $\begin{array}{l}\text { Dianthus barbatus } \quad \text { L. } \quad- \\
\text { turski karanfil }\end{array}$ & $\begin{array}{l}\text { Turski karanfil razgranat je u obliku grma, listovi su } \\
\text { zelene do plavozelene boje. Cvjetovi su izrazito ugodn }\end{array}$ \\
\hline
\end{tabular}




\begin{tabular}{|c|c|c|}
\hline \multirow{2}{*}{\multicolumn{2}{|c|}{ Odabrane trajnice }} & Morfološke i uzgojne karakteristike \\
\hline & & $\begin{array}{l}\text { skupljeni u cvjetne glavice. Cvjetovi mogu biti različitih boja } \\
\text { (bijela, ružičasta, purpurna, crvena, ljubičasta). Cvate u rano ljeto, } \\
\text { od svibnja do lipnja. Preferira sunčane i polusjenovite položaje. } \\
\text { Voli plodna, dobro propusna tla (Strukić, 2014). }\end{array}$ \\
\hline & $\begin{array}{l}\text { Chrysanthemum indicum } \\
\text { L. - krizantema }\end{array}$ & $\begin{array}{l}\text { Krizantema raste u obliku grma, listovi su cjeloviti, nazubljeni ili } \\
\text { perasti, srebrno zelene boje, te se nalaze na čvrstim ili drvenastim } \\
\text { stabljikama. Postoje kultivari velikocvjetnih i sitnocvjetnih te } \\
\text { jednostrukih i dvostrukih cvatova. Boja cvatova može biti bijela, } \\
\text { žuta, narančasta, ružičasta, ljubičasta, crvena i smeđa. Postoje } \\
\text { rani, srednji i kasnojesenski kultivari. Preferira sunčane do } \\
\text { polusunčane položaje. Otporna je na zimu i kasne jesenske } \\
\text { mrazove. Voli teško, hranjivo, glinasto pjeskovito tlo (Strukić, } \\
\text { 2014). }\end{array}$ \\
\hline & $\begin{array}{l}\text { Lavandula angustifolia } \\
\text { Mill. - lavanda }\end{array}$ & $\begin{array}{l}\text { Lavanda je zimzeleni polugrm koji naraste u visinu } 40-100 \mathrm{~cm} \text {. } \\
\text { Listovi su uski, sivozelene boje s uspravnim cvatnim stapkama } \\
\text { koje nose plave cvatove. Ovisno o kultivaru, cvatovi mogu biti i } \\
\text { ljubičaste, ružičaste ili bijele boje. Vrijeme cvatnje je od lipnja do } \\
\text { srpnja. Preferira sunčane položaje. Voli alkalna tla, ako je pak tlo } \\
\text { kiselo treba mu dodati vapna (Strukić, 2014). }\end{array}$ \\
\hline & $\begin{array}{l}\text { Helichrysum italicum } \\
\text { (Roth) G. Don. fil. - smilje }\end{array}$ & $\begin{array}{l}\text { Smilje raste u obliku grmlja visine } 30-70 \mathrm{~cm} \text {. Na razgranatim } \\
\text { stabljikama smilja naizmjenično su raspoređeni listići koji su s } \\
\text { lica zeleni, a s naličja sivozeleni, prekriveni sivim dlačicama. } \\
\text { Donji listovi su pri osnovi skupljeni u rozetu. Sitni cvjetići } \\
\text { skupljeni su u žute cvatove. Cvjeta od lipnja do kolovoza. } \\
\text { Zahtjeva dosta sunčevog svjetla. Dobro uspijeva na lako } \\
\text { propusnim karbonatnim tlima. Dobro podnosi sušu i minimalnu } \\
\text { količinu hraniva (Hessayon, 2004). }\end{array}$ \\
\hline
\end{tabular}

\section{Rezultati anketnog istraživanja}

U sljedećim tablicama (Tablice 2. - 11.) prikazani su rezultati općih saznanja o pojedinim vrstama trajnica.

Tablica 2. Percepcije o ukrasnim karakteristikama i primjeni bršljana.

Table 2. Perceptions of ornamental characteristics and application of common ivy.

\begin{tabular}{|c|l|c|c|}
\hline $\begin{array}{c}\text { Redni } \\
\text { broj }\end{array}$ & \multicolumn{1}{|c|}{ Pitanje } & $\begin{array}{c}\text { Aritmetička } \\
\text { sredina }\end{array}$ & $\begin{array}{c}\text { Standardna } \\
\text { devijacija }\end{array}$ \\
\hline 1. & $\begin{array}{l}\text { Ocijenite atraktivnost primjene bršljana u vrtovima i na } \\
\text { krajobraznim površinama }\end{array}$ & 3,80 &, 948 \\
\hline 2. & Ocijenite ukrasne karakteristike lista i habitusa bršljana & 3,98 &, 869 \\
\hline 3. & Ocijenite ukrasne karakteristike cvijeta bršljana & 3,18 & 1,173 \\
\hline 4. & Ocijenite ukrasne karakteristike ploda bršljana & 3,08 & 1,140 \\
\hline 5. & $\begin{array}{l}\text { Ocijenite način održavanja bršljana (1 - izrazito teško, 5- } \\
\text { lagano) }\end{array}$ & 4,14 & 1,069 \\
\hline 6. & Ocijenite utjecaj bršljana na čovjekovo raspoloženje & 3,52 & 1,182 \\
\hline
\end{tabular}


B. Dorbić, Lea Zemunović, Tea Zemunović, Emilija Friganović, Elma Temim, Katica Arar / Istraživanje općih saznanja o nekim vrstama trajnica na Med... / Glasilo Future (2018) 1 (5-6) 01-12

Iz Tablice 2. vidljivo je da je bršljan vrlo atraktivan za primjenu u vrtovima i na krajobraznim površinama. Ukrasne karakteristike lista i habitusa te utjecaj bršljana na čovjekovo raspoloženje ocijenjene su vrlo dobrim ocjenama. Dekorativne karakteristike cvijeta i ploda vrednuju ocjenom dobar, a održavanje bršljana ocjenjuju uglavnom kao lako.

Tablica 3. Percepcije o ukrasnim karakteristikama i primjeni ciklame.

Table 3. Perceptions of decorative characteristics and application of sowbread.

\begin{tabular}{|c|l|c|c|}
\hline $\begin{array}{c}\text { Redni } \\
\text { broj }\end{array}$ & \multicolumn{1}{|c|}{ Pitanje } & $\begin{array}{c}\text { Aritmetička } \\
\text { sredina }\end{array}$ & $\begin{array}{c}\text { Standardna } \\
\text { devijacija }\end{array}$ \\
\hline 1. & $\begin{array}{l}\text { Ocijenite atraktivnost primjene ciklame u vrtovima i na } \\
\text { krajobraznim površinama }\end{array}$ & 4,44 &, 611 \\
\hline 2. & Ocijenite ukrasne karakteristike lista i habitusa ciklame & 4,34 &, 772 \\
\hline 3. & Ocijenite ukrasne karakteristike cvijeta ciklame & 4,62 &, 530 \\
\hline 4. & Ocijenite miris cvijeta ciklame & 3,80 &, 989 \\
\hline 5. & $\begin{array}{l}\text { Ocijenite način održavanja ciklame (1 - izrazito teško, 5- } \\
\text { lagano) }\end{array}$ & 3,76 &, 938 \\
\hline 6. & Ocijenite utjecaj ciklame na čovjekovo raspoloženje & 4,30 &, 789 \\
\hline
\end{tabular}

U Tablici 3. vidljivo je kako su ukrasne karakteristike lista i habitusa, miris cvijeta i primjena ciklame ocijenjene vrlo dobrim ocjenama. Također, s vrlo dobrim ocjenjuju i utjecaj ciklame na čovjekovo raspoloženje. Ispitanici su ocjenu odličan dodijelili ukrasnim karakteristikama cvijeta ciklame. Način održavanja procjenjuju kao uglavnom lagano.

Tablica 4. Percepcije o ukrasnim karakteristikama i primjeni čuvarkuće.

Table 4. Perceptions of decorative characteristics and application of common houseleek.

\begin{tabular}{|c|l|c|c|}
\hline $\begin{array}{c}\text { Redni } \\
\text { broj }\end{array}$ & \multicolumn{1}{|c|}{ Pitanje } & $\begin{array}{c}\text { Aritmetička } \\
\text { sredina }\end{array}$ & $\begin{array}{c}\text { Standardna } \\
\text { devijacija }\end{array}$ \\
\hline 1. & $\begin{array}{l}\text { Ocijenite atraktivnost primjene čuvarkuće u vrtovima i na } \\
\text { krajobraznim površinama }\end{array}$ & 4,18 &, 800 \\
\hline 2. & Ocijenite ukrasne karakteristike lista i habitusa čuvarkuće & 4,10 &, 953 \\
\hline 3. & Ocijenite ukrasne karakteristike cvjetne stapke čuvarkuće & 3,92 &, 986 \\
\hline 4. & Ocijenite ukrasne karakteristike cvijeta čuvarkuće & 3,96 &, 968 \\
\hline 5. & $\begin{array}{l}\text { Ocijenite način održavanja čuvarkuće (1 - izrazito teško, 5- } \\
\text { lagano) }\end{array}$ & 4,52 &, 995 \\
\hline 6. & Ocijenite utjecaj čuvarkuće na čovjekovo raspoloženje & 4,28 &, 858 \\
\hline
\end{tabular}

Iz Tablice 4. razvidno je da su sve ukrasne karakteristike i primjena čuvarkuće ocijenjene vrlo dobrim ocjenama. Način održavanja ove vrste ispitanici percipiraju kao lagan. 

Istraživanje općih saznanja o nekim vrstama trajnica na Med... / Glasilo Future (2018) 1 (5-6) 01-12

Tablica 5. Percepcije o ukrasnim karakteristikama i primjeni hortenzije.

Table 5. Perceptions of decorative characteristics and application of hortensia .

\begin{tabular}{|c|l|c|c|}
\hline $\begin{array}{c}\text { Redni } \\
\text { broj }\end{array}$ & \multicolumn{1}{|c|}{ Pitanje } & $\begin{array}{c}\text { Aritmetička } \\
\text { sredina }\end{array}$ & $\begin{array}{c}\text { Standardna } \\
\text { devijacija }\end{array}$ \\
\hline 1. & $\begin{array}{l}\text { Ocijenite atraktivnost primjene hortenzije u vrtovima i na } \\
\text { krajobraznim površinama }\end{array}$ & 4,66 &, 592 \\
\hline 2. & Ocijenite ukrasne karakteristike lista i habitusa hortenzije & 4,64 &, 631 \\
\hline 3. & Ocijenite ukrasne karakteristike cvata hortenzije & 4,70 &, 544 \\
\hline 4. & $\begin{array}{l}\text { Ocijenite način održavanja hortenzije (1 - izrazito teško, 5 - } \\
\text { lagano) }\end{array}$ & 3,86 &, 926 \\
\hline 5. & Ocijenite utjecaj hortenzije na čovjekovo raspoloženje & 4,46 &, 706 \\
\hline 6. & $\begin{array}{l}\text { Ocijenite atraktivnost primjene hortenzije u vrtovima i na } \\
\text { krajobraznim površinama }\end{array}$ & 4,66 &, 592 \\
\hline
\end{tabular}

Iz Tablice 5. je razvidno da su atraktivnost primjene hortenzije u vrtovima i na krajobraznim površinama te njene ukrasne karakteristike ocijenjene ocjenom odličan. Način održavanja procjenjuju kao uglavnom lagan, a utjecaj hortenzije na čovjekovo raspoloženje ocijenjen je vrlo dobrom ocjenom.

Tablica 6. Percepcije o ukrasnim karakteristikama i primjeni jaglaca.

Table 6. Perceptions of decorative characteristics and application of primrose.

\begin{tabular}{|c|l|c|c|}
\hline $\begin{array}{c}\text { Redni } \\
\text { broj }\end{array}$ & \multicolumn{1}{|c|}{ Pitanje } & $\begin{array}{c}\text { Aritmetička } \\
\text { sredina }\end{array}$ & $\begin{array}{c}\text { Standardna } \\
\text { devijacija }\end{array}$ \\
\hline 1. & $\begin{array}{l}\text { Ocijenite atraktivnost primjene jaglaca u vrtovima i na } \\
\text { krajobraznim površinama }\end{array}$ & 4,12 &, 895 \\
\hline 2. & Ocijenite ukrasne karakteristike lista i habitusa jaglaca & 4,16 &, 889 \\
\hline 3. & Ocijenite ukrasne karakteristike cvijeta jaglaca & 4,28 &, 834 \\
\hline 4. & $\begin{array}{l}\text { Ocijenite način održavanja jaglaca (1 - izrazito teško, 5- } \\
\text { lagano) }\end{array}$ & 3,92 &, 922 \\
\hline 5. & Ocijenite utjecaj jaglaca na čovjekovo raspoloženje & 4,22 &, 910 \\
\hline
\end{tabular}

U Tablici 6. vidljivo je da su ukrasne i krajobrazne vrijednosti jaglaca ocijenjene s ocjenom vrlo dobar. Način održavanja procjenjuju kao uglavnom lagan.

Iz Tablice 7. razvidno je da su ukrasne i krajobrazne vrijednosti kadulje ocijenjene ocjenom vrlo dobar. Način održavanja procjenjuju kao uglavnom lagan.

Tablica 8. pokazuje da su ukrasne karakteristike cvijeta ocijenjene najvećom ocjenom (odličan). Ostale karakteristike su ocijenjene vrlo dobrim ocjenama. Način održavanja vide kao uglavnom lagan. 

Istraživanje općih saznanja o nekim vrstama trajnica na Med... / Glasilo Future (2018) 1 (5-6) 01-12

Tablica 7. Percepcije o ukrasnim karakteristikama i primjeni kadulje.

Table 7. Perceptions of decorative characteristics and application of common sage.

\begin{tabular}{|c|l|c|c|}
\hline $\begin{array}{c}\text { Redni } \\
\text { broj }\end{array}$ & \multicolumn{1}{|c|}{ Pitanje } & $\begin{array}{c}\text { Aritmetička } \\
\text { sredina }\end{array}$ & $\begin{array}{c}\text { Standardna } \\
\text { devijacija }\end{array}$ \\
\hline 1. & $\begin{array}{l}\text { Ocijenite atraktivnost primjene kadulje u vrtovima i na } \\
\text { krajobraznim površinama }\end{array}$ & 4,20 &, 903 \\
\hline 2. & Ocijenite ukrasne karakteristike lista i habitusa kadulje & 4,06 &, 956 \\
\hline 3. & Ocijenite ukrasne karakteristike cvijeta kadulje & 4,18 &, 873 \\
\hline 4. & Ocijenite miris kadulje & 4,48 &, 707 \\
\hline 5. & $\begin{array}{l}\text { Ocijenite način održavanja kadulje (1 - izrazito teško, 5- } \\
\text { lagano) }\end{array}$ & 4,22 &, 996 \\
\hline 6. & Ocijenite utjecaj kadulje na čovjekovo raspoloženje & 4,36 &, 749 \\
\hline
\end{tabular}

Tablica 8. Percepcije o ukrasnim karakteristikama i primjeni turskog karanfila.

Table 8. Perceptions of decorative characteristics and application of sweet William.

\begin{tabular}{|c|l|c|c|}
\hline $\begin{array}{c}\text { Redni } \\
\text { broj }\end{array}$ & \multicolumn{1}{|c|}{ Pitanje } & $\begin{array}{c}\text { Aritmetička } \\
\text { sredina }\end{array}$ & $\begin{array}{c}\text { Standardna } \\
\text { devijacija }\end{array}$ \\
\hline 1. & $\begin{array}{l}\text { Ocijenite atraktivnost primjene turskog karanfila u vrtovima i } \\
\text { na pejsažnim površinama }\end{array}$ & 4,34 &, 798 \\
\hline 2. & $\begin{array}{l}\text { Ocijenite ukrasne karakteristike lista i habitusa turskog } \\
\text { karanfila }\end{array}$ & 4,24 &, 916 \\
\hline 3. & Ocijenite ukrasne karakteristike cvijeta turskog karanfila & 4,62 &, 635 \\
\hline 4. & Ocijenite miris cvijeta turskog karanfila & 3,90 & 1,015 \\
\hline 5. & $\begin{array}{l}\text { Ocijenite način održavanja turskog karanfila (1 - izrazito } \\
\text { teško, 5 - lagano) }\end{array}$ & 3,64 & 1,025 \\
\hline 6. & Ocijenite utjecaj turskog karanfila na čovjekovo raspoloženje & 4,28 &, 783 \\
\hline
\end{tabular}

Tablica 9. Percepcije o ukrasnim karakteristikama i primjeni krizanteme.

Table 9. Perceptions of decorative characteristics and application.

\begin{tabular}{|c|l|c|c|}
\hline $\begin{array}{c}\text { Redni } \\
\text { broj }\end{array}$ & \multicolumn{1}{|c|}{ Pitanje } & $\begin{array}{c}\text { Aritmetička } \\
\text { sredina }\end{array}$ & $\begin{array}{c}\text { Standardna } \\
\text { devijacija }\end{array}$ \\
\hline 1. & $\begin{array}{l}\text { Ocijenite atraktivnost primjene krizantema u vrtovima i na } \\
\text { krajobraznim površinama }\end{array}$ & 4,14 &, 926 \\
\hline 2. & Ocijenite ukrasne karakteristike lista i habitusa krizanteme & 4,00 &, 969 \\
\hline 3. & Ocijenite ukrasne karakteristike cvijeta krizanteme & 4,04 & 1,029 \\
\hline 4. & Ocijenite miris krizanteme & 3,66 & 1,042 \\
\hline 5. & $\begin{array}{l}\text { Ocijenite način održavanja krizanteme(1 - izrazito teško, } 5- \\
\text { lagano) }\end{array}$ & 3,76 &, 959 \\
\hline 6. & Ocijenite utjecaj krizanteme na čovjekovo raspoloženje & 3,86 & 1,178 \\
\hline
\end{tabular}


B. Dorbić, Lea Zemunović, Tea Zemunović, Emilija Friganović, Elma Temim, Katica Arar / Istraživanje općih saznanja o nekim vrstama trajnica na Med... / Glasilo Future (2018) 1 (5-6) 01-12

Iz Tablice 9. vidljivo je da je većina ukrasnih i krajobraznih karakteristika za krizantemu ocijenjena ocjenom vrlo dobar. Iznenađuje, čak da su ispitanici pomalo neobičnom mirisu krizanteme također dodijelili ocjenu vrlo dobar. Način održavanja vide kao uglavnom lagan.

Tablica 10. Percepcije o ukrasnim karakteristikama i primjeni lavande.

Table 10. Perceptions of decorative characteristics and application of lavender.

\begin{tabular}{|c|l|c|c|}
\hline $\begin{array}{c}\text { Redni } \\
\text { broj }\end{array}$ & \multicolumn{1}{|c|}{ Pitanje } & $\begin{array}{c}\text { Aritmetička } \\
\text { sredina }\end{array}$ & $\begin{array}{c}\text { Standardna } \\
\text { devijacija }\end{array}$ \\
\hline 1. & $\begin{array}{l}\text { Ocijenite atraktivnost primjene lavande u vrtovima i na } \\
\text { krajobraznim površinama }\end{array}$ & 4,52 &, 646 \\
\hline 2. & Ocijenite ukrasne karakteristike lista i habitusa lavande & 4,34 &, 848 \\
\hline 3. & Ocijenite ukrasne karakteristike cvijeta lavande & 4,48 &, 707 \\
\hline 4. & Ocijenite miris lavande & 4,40 &, 907 \\
\hline 5. & $\begin{array}{l}\text { Ocijenite način održavanja lavande (1 - izrazito teško, 5- } \\
\text { lagano) }\end{array}$ & 4,30 &, 789 \\
\hline 6. & Ocijenite utjecaj lavande na čovjekovo raspoloženje & 4,38 &, 854 \\
\hline
\end{tabular}

U Tablici 10. vidljivo je da su sve varijable dobile visoke ocjene, s tim da je atraktivnost lavande za primjenu u vrtovima i na krajobraznim površinama dobila ocjenu odličan.

Tablica 11. Percepcije o ukrasnim karakteristikama i primjeni smilja.

Table 11. Perceptions of decorative characteristics and application of immortelle.

\begin{tabular}{|c|l|c|c|}
\hline $\begin{array}{c}\text { Redni } \\
\text { broj }\end{array}$ & \multicolumn{1}{|c|}{ Pitanje } & $\begin{array}{c}\text { Aritmetička } \\
\text { sredina }\end{array}$ & $\begin{array}{c}\text { Standardna } \\
\text { devijacija }\end{array}$ \\
\hline 1. & $\begin{array}{l}\text { Ocijenite atraktivnost primjene smilja u vrtovima i na } \\
\text { krajobraznim površinama }\end{array}$ & 4,10 & 1,015 \\
\hline 2. & Ocijenite ukrasne karakteristike lista i habitusa smilja & 3,84 &, 955 \\
\hline 3. & Ocijenite ukrasne karakteristike cvijeta smilja & 4,04 &, 925 \\
\hline 4. & Ocijenite miris smilja & 3,78 & 1,234 \\
\hline 5. & $\begin{array}{l}\text { Ocijenite način održavanja smilja (1 - izrazito teško, 5- } \\
\text { lagano) }\end{array}$ & 3,88 & 1,023 \\
\hline 6. & Ocijenite utjecaj smilja na čovjekovo raspoloženje & 4,08 & 1,047 \\
\hline
\end{tabular}

Iz Tablice 11. vidljivo je da su sve varijable dobile visoke vrlo dobre ocjene.

Rezimirajući navedeno došli smo do sljedećih prosječnih ocjena za odabrane vrste trajnica:

- bršljan, ukrasne karakteristike $(3,41)$, atraktivnost primjene $(3,80)$ i utjecaj na čovjekovo raspoloženje $(3,52)$; 
B. Dorbić, Lea Zemunović, Tea Zemunović, Emilija Friganović, Elma Temim, Katica Arar / Istraživanje općih saznanja o nekim vrstama trajnica na Med... / Glasilo Future (2018) 1 (5-6) 01-12

- ciklama, ukrasne karakteristike $(4,25)$, atraktivnost primjene $(4,44)$ i utjecaj na čovjekovo raspoloženje $(4,30)$;

- čuvarkuća, ukrasne karakteristike $(3,99)$, atraktivnost primjene $(4,18)$ i utjecaj na čovjekovo raspoloženje $(4,28)$;

- hortenzija, ukrasne karakteristike $(4,67)$, atraktivnost primjene $(4,66)$ i utjecaj na čovjekovo raspoloženje $(4,46)$;

- jaglac, ukrasne karakteristike $(4,22)$, atraktivnost primjene $(4,12)$ i utjecaj na čovjekovo raspoloženje $(4,22)$;

- kadulja, ukrasne karakteristike $(4,24)$, atraktivnost primjene $(4,20)$ i utjecaj na čovjekovo raspoloženje $(4,36)$;

- turski karanfil, ukrasne karakteristike $(4,25)$, atraktivnost primjene $(4,34)$ i utjecaj na čovjekovo raspoloženje $(4,28)$;

- $\quad$ krizantema, ukrasne karakteristike $(3,90)$, atraktivnost primjene $(4,14)$ i utjecaj na čovjekovo raspoloženje $(3,86)$;

- lavanda, ukrasne karakteristike $(4,41)$, atraktivnost primjene $(4,52)$ i utjecaj na čovjekovo raspoloženje $(4,38)$;

- smilje, ukrasne karakteristike $(3,89)$, atraktivnost primjene $(4,10)$ i utjecaj na čovjekovo raspoloženje $(4,08)$.

Iz gore navedenog razvidno je da su ispitanici u pogledu vrednovanja ukrasnih karakteristika najbolje ocjene dodijelili hortenziji $(4,67)$ koja je česta u uporabi (pojedinačno ili u grupama) na Mediteranu i submediteranu. Potom slijedi lavanda $(4,41)$ koja se zadnjih desetljeća sve više koristi u ukrasnoj hortikulturi. Ponešto lošije ocjene u ovoj skupini su dodijeljene: turskom karanfilu $(4,25)$ čiji slatkasti miris podsjeća na djetinjstvo, ciklami s prekrasnim ružičastim cvjetovima, kadulji $(4,24)$ te jaglacu s prepoznatljivim žutim cvjetovima u rano proljeće $(4,22)$. Čuvarkuća, krizantema i smilje su ocijenjeni u rasponu $(3,89-3,99)$.

$\mathrm{U}$ pogledu atraktivnosti primjene trajnica u vrtovima i na krajobraznim površinama najbolje su ocijenjene sljedeće vrste: hortenzija $(4,66)$, lavanda $(4,52)$, ciklama $(4,44)$, turski karanfil $(4,34)$, kadulja $(4,20)$, čuvarkuća $(4,18)$ itd. Neke od navedenih vrsta, osim svojih dekorativnih osobina, uzgajane su i kao utilitarne vrste [za začin (lavanda, kadulja), za privlačenje pčela i leptira (turski karanfil), za liječenje uhobolje (čuvarkuća)] (Židovec et al., 2006b). U posljednje vrijeme sve se više govori o bio raznolikosti i uvođenju te uporabi autohtonih vrsta u gradske krajobraze na Mediteranu i submediteranu stoga dobiveni rezultati preferencija odgovaraju navedenom trendu (Dorbić et al., 2012; Perinčić et al., 2016; Židovec et al., 2006a). U pogledu utjecaja trajnica na čovjekovo raspoloženje najbolje su ocijenjene sljedeće vrste: hortenzija $(4,46)$, lavanda $(4,38)$, kadulja $(4,36)$, ciklama $(4,30)$, čuvarkuća i turski karanfil $(4,28)$ itd. Način održavanja trajnica ispitanici percipiraju u rasponu od uglavnom lagano do lagano. 


\section{Zaključak}

Temeljem rezultata anketnog istraživanja može se zaključiti da su ispitanici, u pogledu vrednovanja ukrasnih karakteristika i primjene, bolje ocjene (izvrstan i vrlo dobar) dodijelili vrstama koje se tradicijski dugo uzgajaju na našim prostorima (npr. hortenzija, ciklama, turski karanfil) i nekim autohtonim vrstama trajnica (lavanda, kadulja). Nešto lošije vrlo dobre ocjene dobile su ostale vrste. Zanimljivo je prokomentirati i da je smilje dobilo nešto niže ocjene premda se u posljednje vrijeme propagira njegova sadnja i primjena u ukrasnoj hortikulturi. Preferencija za navedeno ovisi o sadašnjim trendovima u proizvodnji i primjeni ukrasnog bilja, spolu ispitanika, društvenom statusu, okolini itd. Način održavanja percipiraju u rasponu od uglavnom lagano do lagano.

\section{Zahvala}

Rad je izrađen u okviru seminarskih radova studentica Lee i Tee Zemunović s preddiplomskog stručnog studija Poljoprivreda krša smjer Biljna proizvodnja na Veleučilištu "Marko Marulić" u Kninu.

\section{Literatura}

Dorbić, B., Gaćina, N., Krnčević, M., Krnčević, Ž., Srpak, M. (2012). Krajobrazno uređenje i zaštita ruralnog okoliša starokršćanske crkve Srima-Prižba kod Šibenika s posebnim osvrtom na gastronomske vrijednosti u svrhu turističke valorizacije. Zbornik radova Međimurskog veleučilišta $u$ Čakovcu, 3(2), 23-31.

Dorbić, B., Davitkovska, M., Temim, E., Pamuković, A. (2018). Ukrasno bilje - Uzgoj i primjena. Šibenik: Ogranak Matice hrvatske u Šibeniku.

Dubravec, K.-D. (1996). Botanika. Zagreb: Agronomski fakultet.

Hessayon, D. G. (2004). Cvijeće u vrtu. Zagreb: Mozaik knjiga.

Kantoci, D. (2011). Dobrodošli u svijet trajnica. Glasnik Zaštite Bilja 34(4), 6-13.

Krajičak, J., Milakara, J., Židovec, V., Hima, V. (2013). Cvjetne vrste okućnica u zaštićenoj ruralnoj cjelini krapje. Agronomski glasnik, 75(2-3), 135-146.

Krauter, L. (2008). Biovrt: Povrtnjak, voćnjak, cvijetnjak: Biološko, organsko, prirodno. Split: Marjan tisak d.o.o.

Mcdonald, E. (2004). 400 vrtnih biljaka za uređenje okućnice. Rijeka: Dušević\&Krišovnik.

Perinčić, B., Franin, K., Marcelić, Š., Radović, I. i Židovec, V. (2016). Hortikulturna flora okućnica zadarskog arhipelaga. Agronomski glasnik, 78(4), 171-197. 
B. Dorbić, Lea Zemunović, Tea Zemunović, Emilija Friganović, Elma Temim, Katica Arar / Istraživanje općih saznanja o nekim vrstama trajnica na Med... / Glasilo Future (2018) 1 (5-6) 01-12

Strukić, M. ur. (2014). 200 najpopularnijih biljaka koje ćete lako uzgojiti. Zagreb: Večernji list.

Šilić, Č. (1983). Atlas drveća i grmlja. Sarajevo: Svjetlost.

Židovec, V., Vršek, I., Kolak, I., Liber, Z. i Šatović, Z. (2006a). Mirisava kadulja - Potencijalna vrsta za uređenje krajobraza. Sjemenarstvo, 23(1), 45-56.

Židovec, V., Vršek, I., Ančić, B. i Grzunov, S. (2006b). Tradicijski seoski vrtovi sjeverozapadne Hrvatske. Sjemenarstvo, 23(3), 273-283.

Primljeno: 18. prosinca 2018. godine

Prihvaćeno: 31. prosinca 2018. godine
Received: December 18, 2018

Accepted: December 31, 2018 